Special issue of the 3rd International Conference on Computational and Experimental Science and Engineering (ICCESEN 2016)

\title{
Investigation of Properties of Foam Concretes Produced Using Pumice at Different Ratios
}

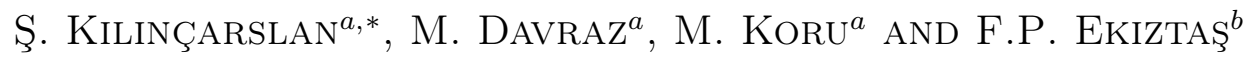 \\ ${ }^{a}$ Suleyman Demirel University, DEYMAM Department, Isparta, Turkey \\ ${ }^{b}$ Suleyman Demirel University, Civil Engineering Department, Isparta, Turkey
}

\begin{abstract}
Foam concrete is a type of light weight concrete having self-compacting properties. It can be obtained by mixing the foam, formed by the foaming agent, with a mixture consisting of cement, water and aggregate. It contains independent closed pores with a volume of $75-80 \%$ within its body. In this study, three series of foam concrete were produced using different ratio of pumice. Compressive strength, splitting tensile strength and thermal conductivity of foam concrete samples were determined for each density set. It is found that, pumice ratio has a linear relationships with dry bulk density, compressive strength, tensile strength and thermal conductivity. It can also be concluded that strong relationship exist between higher correlation coefficients and pumice ratio.
\end{abstract}

DOI: 10.12693/APhysPolA.132.708

PACS/topics: 65.60.+a, 62.20.mt

\section{Introduction}

Properties of materials used in construction of buildings are important for both the durability and to carry architectural culture to next generation $[1,2]$. The pumice, formed after volcanic event, has a lot of cavities. It is a spongy, porous and light building material $[3,4]$. As the estimated reserve of pumice in Turkey is very high, it becomes an important material in engineering sectors [5].

Instead of using a single type of building material, using a mixture of them is more useful. Thus a number of problems with mechanical deformation, thermal and voice conductivity can be solved [6]. The foam concrete has an excellent resistance to water and frost [7]. Foam concrete is an environmentally friendly building and insulation material that provides heat and impact sound insulation. It is lightweight and non-harmful to human health $[8,9]$. When foam concrete is in fresh state, it has a high flow capability. After hardening, it has low density, function-dependent strength and low thermal conductivity properties. Generally, its dry density is around $400-1600 \mathrm{~kg} / \mathrm{m}^{3}$, while its compressive strength is in the range of 1-15 $\mathrm{MPa}$. In recent years it has become widespread in the semi structural or non-structural construction applications [10].

\section{Materials and methods}

\subsection{Materials}

The aim of this work is to study foam concrete, prepared by mixing cement, pumice powder, super plasticizer and protein-based foaming agent, with the dry density in the range of $400-500 \mathrm{~kg} / \mathrm{m}^{3}$. Three different series of

\footnotetext{
* corresponding author; e-mail: seref@tef.sdu.edu.tr
}

foam concrete design mixes were prepared with (i) $100 \%$ limestone aggregate, (ii) $50 \%$ to $50 \%$ pumice-limestone aggregate, and (iii) $100 \%$ pumice aggregate.

According to the targeted theoretical density for each mix design, mixture components were calculated based on the amount of volume. In all mixtures, cement dosage was kept at $300 \mathrm{~kg} / \mathrm{m}^{3}$ and water/solid (w/s) ratio was held constant at 0.30 . The dry density and component amounts for $1 \mathrm{~m}^{3}$ of mixture are given in Table I. The mixtures were prepared by mixing cement, limestone powder, water and plasticizer. Foam with a density of $80 \mathrm{~g} / \mathrm{l}$, in average, was added to the mixtures until theoretical fresh density value was reached according to the mix designs.

TABLE I

The mix designs of foam concretes.

\begin{tabular}{c|c|c|c|c|c|c|c}
\hline \hline Series & $\begin{array}{c}D_{\text {dry }} \\
{\left[\mathrm{kg} / \mathrm{m}^{3}\right]}\end{array}$ & $\begin{array}{c}\text { Cement } \\
{[\mathrm{g}]}\end{array}$ & $\begin{array}{c}\text { Limestone } \\
{[\mathrm{g}]}\end{array}$ & $\begin{array}{c}\text { Pumice } \\
{[\mathrm{g}]}\end{array}$ & $\begin{array}{c}\text { Water } \\
{[\mathrm{g}]}\end{array}$ & $\begin{array}{c}\text { Plasticizer } \\
{[\mathrm{g}]}\end{array}$ & Foam \\
\hline $\mathrm{g}]$
\end{tabular}

\subsection{Methods}

The compressive strength and splitting tensile strength of specimens were tested under dried air conditions. The production and experiments with all specimens were conducted in Natural and Industrial Building Materials Research Centre of Suleyman Demirel University. The standards used in the experiments are given in Table II.

\section{Results and discussion}

The results of compressive strength, splitting tensile strength tests and ultrasonic pulse velocity tests were conducted with foam concrete specimens after the 28-day 


\section{TABLE II}

The standards used in the experiments.

\begin{tabular}{c|c|c}
\hline \hline Experimental & Standards & Sample shape \\
\hline Dry densities & TS EN 678 & Unit volume \\
Compressive strength & TS EN 1354 & $15 \mathrm{~cm}^{3}$ \\
Splitting tensile stren. & TS EN 12390-6 & $15 \mathrm{~cm}^{3}$ \\
Thermal conductivity & TS EN 12667 & $30 \times 30 \times 5 \mathrm{~cm}^{3}$
\end{tabular}

curing period. Compressive strength $f_{\mathrm{c}}$, splitting tensile strength $f_{\text {ct }}$, ultrasonic pulse velocities $V_{\mathrm{p}}$ of foam concrete samples were determined according to arithmetic mean of results of three measurements for each density set. The results as functions of density $\rho_{\mathrm{gk}}$ of specimens are given in Table III.

\section{TABLE III}

Average results of compressive strength, splitting tensile strength and thermal conductivity of foam concrete specimens after 28 days of curing.

\begin{tabular}{c|c|c|c|c}
\hline \hline Series & $\begin{array}{c}\rho_{g k} \\
{\left[\mathrm{~kg} / \mathrm{m}^{3}\right]}\end{array}$ & $\begin{array}{c}f_{\mathrm{c}-28} \\
{[\mathrm{MPa}}\end{array}$ & $\begin{array}{c}f_{\mathrm{ct}-28} \\
{[\mathrm{MPa}]}\end{array}$ & $\begin{array}{c}\text { Thermal } \\
\text { conductivity } \\
{[\mathrm{W} / \mathrm{mK}]}\end{array}$ \\
\hline PKB & 0.402 & 0.374 & 0.071 & 0.0882 \\
$\mathrm{KKB}$ & 0.480 & 0.756 & 0.113 & 0.1058 \\
NKB & 0.504 & 0.938 & 0.136 & 0.1103
\end{tabular}

The variations of compressive strength, splitting tensile strength and thermal conductivity versus dry density have been plotted in Fig. 1. It is seen that there is a strong relationship between dry density, compressive strength, splitting tensile strength and thermal conductivity coefficient in the foam concrete.
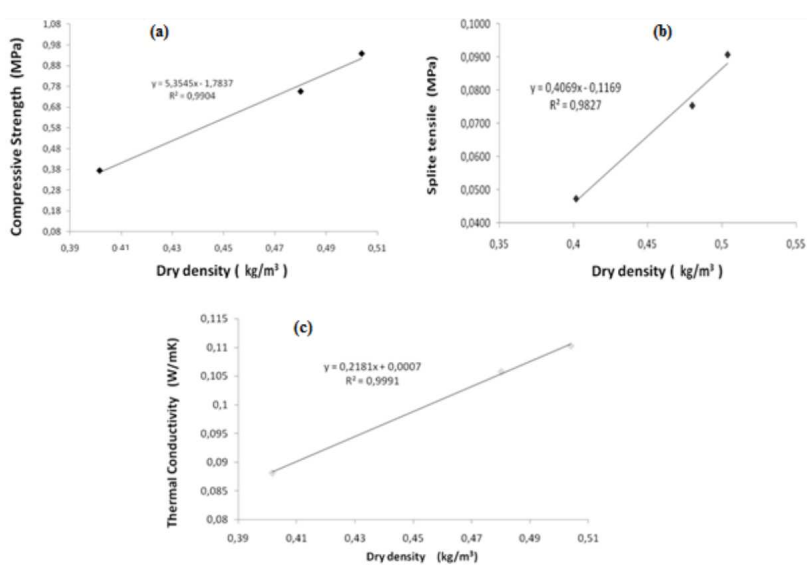

Fig. 1. The variation of (a) compressive strength, (b) splitting tensile strength and (c) thermal conductivity with dry density.

\section{Conclusions}

As a result of the study, the relationships of values of compressive strength and thermal conductivity coefficient with dry density were proposed for foam concretes. It is seen that there is a strong relationship between dry density - compressive strength and dry density - thermal conductivity coefficient in the foam concrete. It is found that pumice ratio has a linear relationships with dry bulk density, compressive strength, tensile strength and thermal conductivity. It can also be concluded that strong relationships exist between higher correlation coefficients and pumice ratio.

\section{References}

[1] I. Akkurt, H. Akyıldırım, B. Mavi, S. Kilincarslan, C. Basyigit, Ann. Nucl. Energy. 37, 910 (2010).

[2] I. Akkurt, C. Basyigit, S. Kilincarslan, B. Mavi, A. Akkurt, Cement Concrete Compos. 28, 153 (2006).

[3] M. Davraz, Ş. Kılınçarslan, H. Ceylan, Acta Phys. Pol. A 128, 184 (2015).

[4] I. Akkurt, H. Akyildirim, Nucl. Engin. Design 252, 163 (2012).

[5] A. Beycioğlu, C. Başyiğit, Acta Phys. Pol. A 128, B-424 (2015).

[6] I. Akkurt, H. Akyildirim, B. Mavi, S. Kilingarslan, C. Başyigit, Acta Phys. Pol. A 121, 144 (2012).

[7] E.K. Nambiar, K. Ramamurthy, Cement Concrete Compos. 28, 752 (2006).

[8] K. Ramamurthy, E.K. Nambiar, G. Ranjani, Cement Concrete Compos. 31, 388 (2009).

[9] M.R. Jones, A. McCarthy, Fuel 84, 1398 (2005).

[10] M. Davraz, Ş. Kilinçarslan, M. Koru, F. Tuzlak, Acta Phys. Pol. A 130, 469 (2016). 